\title{
Silphium Redux: A Prairie Vision
}

A

half-century ago, reflecting on the passing of the tallgrass

prairies of the Midwest, conservationist Aldo Leopold evoked a vision of a future without prairies.

"What a thousand acres of Silphiums looked like when they tickled the bellies of the buffalo," he wrote in an often-quoted line in "July" of A Sand County Almanac, "is a question never again to be answered, and perhaps not even asked."

The occasion for this remark was the destruction by a road grader of a lone silphium, or compass plant, standing in a tiny remnant of prairie that persisted in an old graveyard along the highway near Leopold's sand county farm.

Leopold, with a poet's eye, saw in the destruction of a few roadsiue "weeds" a fitting symbol of human heedlessness and the death of the prairie. What he apparently did not see was that the act of restoration, represented by the pioneering work he himself was then carrying out on his own farm-as well as with a handful of colleagues at the University of Wisconsin Arboretum just up the road in Madison-was an equally powerful symbol of its resurrection.

This work was well underway by the time Leopold wrote his Almanac. And prominent in the few early photos that clearly show the vegetation on the restoration site at the Arboretum are the spade-shaped leaves of prairie dock, a species of silphiumnot a thousand acres of silphiums, to be sure, but a step in that direction, nevertheless.

Curiously, Leopold never made much of this in his writings. Perhaps the work involved in the restoration seemed to him too great, the results too modest, and the outcome too uncertain to inspire much confidence. Or perhaps he felt that restoration was an idea whose time had not yet come-that people had to realize that they lived in a "world of wounds" before they could be expected to take much interest in environmental healing.

Since Leopold's time, however, the situation has gradually changed. We have continued to lose prairies, but for the first time-perhaps for any ecosystem-we are now restoring them more rapidly than we are destroying them (see page 5). Furthermore, new techniques such as successional restoration are providing ways of avoiding the trade-off of quality for quantity that often beset early restoration efforts on the prairies.

As a result, the scale of high-quality prairie restoration pro- jects is increasing. In fact, the size of the largest projects has increased more or less exponentially during the past 30 years, from tens of hectares at the Morton Arboretum in the 1960s, to hundreds at Fermilab in the '70s, and now into the thousands and beyond in projects such as the Walnut Creek project in lowa (see page 16) and those Ed Collins is undertaking for the McHenry County Conservation District west of Chicago.

At the same time restorationists are discovering new applications and new opportunities for prairie restoration. Examples range from landscaping projects and backyard prairie gardens and seed-orchards to applications in game and watershed management, and even to the idea of a prairie agriculture, rotating corn and soybeans with prairie to maintain the long-term health of the soil.

In my view even more important has been the discovery of restoration itself. I mean the discovery of restoration as a scientific and technical challenge, of course. But even more important is its discovery as an experience and a performing art. It is an act that symbolizes-that enacts- the renewal of the prairie, even as Leopold's silphium symbolized its destruction.

Why is this so important? For a simple reason. It is a way of bringing the prairie into our lives, a way of making it meaningful, not just to a few but to millions. As long as we see restoration merely as a process or a form of technology it is a dead thing. We do it, and the landscape may change. But we don't, and neither does our audience.

On the other hand, once we see restoration as an enriching, transforming experience, it comes to life. It becomes a way not only of making ecosystems, but of making people who will cherish those ecosystems and inhabit them-and invest in their wellbeing.

Sensing this, prairie people today are going beyond nostalgia and regret. They are beginning to talk about the future of the prairie- a future in which large areas, sizeable fractions of whole states, may once again be prairie-not by taking it away from people, but in the only way possible, actually—by giving it back to them.

It is in this spirit, and to help articulate and draw attention to this emerging vision, that we have devoted this issue of REMN to accounts of some of the leading initiatives in prairie restoration. 
This story, we think, is of importance far beyond the tallgrass prairies of the American Midwest. Since Leopold's time, these prairies - in part because they had so nearly vanished-have been the proving ground for the craft of restoration, and today the best work on the prairies is still widely regarded as a model for restoration in its purest form.
What is happening here, I think, offers a model for the future of other ecosystems as well-and ultimately for the future of nature itself in a world increasingly influenced by human activities.

William R. Jordan III

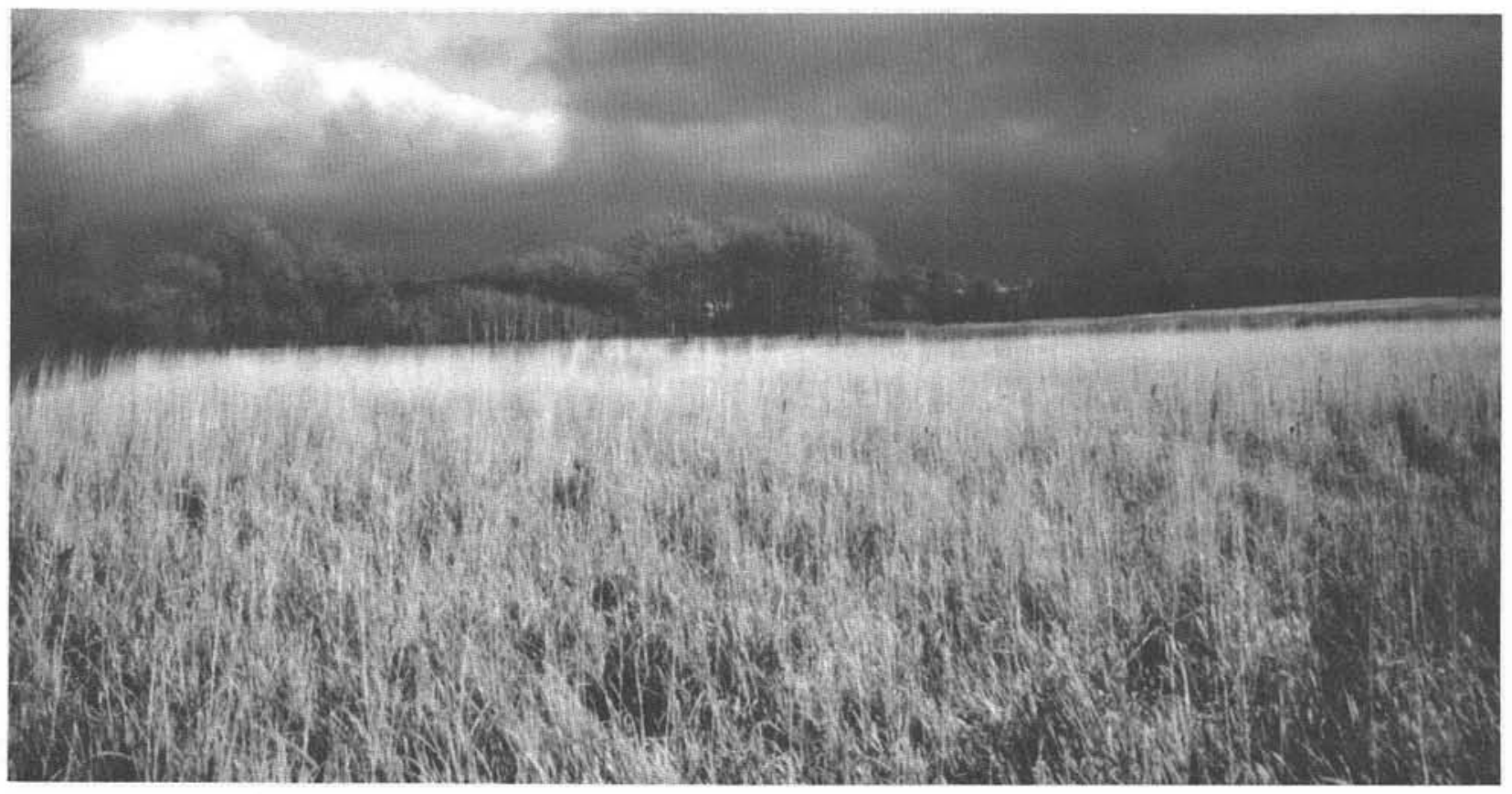

\section{Prairie Dream}

Spread eagle, nose to ground, I breathe Rich prairie loam, pungent, sweet. My left palm sprouts roots;

From each finger, pallid eyes

Seek the ashy soil. My human hand

Sinks taproots deep into the earth.

Up from my right hand shoot grasses,

Tender green and young, spring showy.

Bugs burrow between my fingers;

Sun stirs my skin.

Tall grasses, purple spikes, stars of the prairie, Growing among your riot, I raise my head, Sigh in the breeze. With yours my roots Seek water, nibble nitrogen: a feast
Of stillness, dark and thirsty.

Green, I sip the sun, drink,

Slurp the light. Patient and fierce

I photosynthesize.

I start awake, the rake

Still in my hands, the ache

Teasing my back. I shake

Each foot to loose my roots,

Savor the thin spring sun,

Scape at the sod to make a berth

For seeds: here, now, the earth

And I.

Rinda West 